\title{
Obecné problémy diplomatiky v novověku
}

\author{
Zbyněk Sviták / svitak@phil.muni.cz
}

Ústav pomocných věd historických a archivnictví, Filozofická fakulta, Masarykova univerzita

\begin{abstract}
The article deals with the causes of insufficient reflection of written production in the early and late modern period. It identifies the amount of documents and the issue of their division as the main obstacles to research insofar as they are a prerequisite for mastering the written material. Other problems relate to terminology issues (giving the same document different names), diplomatic terminology's over reliance on archival practice and the uneven depth of development in the various areas of early and late modern diplomatics.
\end{abstract}

\section{Keywords}

diplomatics, written documents, early modern period, late modern period, terminology 
Vědecké zpracování písemností doby novověku není doposud dostatečně rozvinuto. Je možné nalézt dvě zásadní př́ičiny. Zatímco původním zájmem diplomatiky bylo bádání o středověkých listinách, badatelé do písemného materiálu novověkého dějinného období vstoupili daleko později, a to až na samém konci 19 . století. ${ }^{1}$ Druhým důvodem je exponenciálně narůstající absolutní množství písemné produkce, doprovázené rozšiřující se plejádou nových druhů písemností.

Obrovské kvantum písemného materiálu působí ve svém důsledku na badatele spíše demotivačně se silným frustrujícím podtónem. Jeho na první pohled bezbřehost vzbuzuje především silný pocit dezorientace v množství archivního materiálu, který navíc v některých případech stále není uspokojivě uspořádán. S tím souvisí i obava o zabřednutí do něj na dlouhou dobu, což evokuje neobvykle velké množství práce, kterou by bylo třeba vynaložit na dokončení výsledného výstupu. Když se některý z badatelů odhodlal do novověkých materiálů vstoupit, vždy proto zvolil metodu sond, která jedině mohla přinést alespoň základní podchycení nějakého tématu novověké diplomatiky. ${ }^{2}$

Badatelé, kteří se jako prospektoři odvážně pouštějí do novověkého diplomatického materiálu, narážejí na různé problémy, které vyplývají právě z jeho nedostatečného uchopení obsahového i terminologického.

\section{Písemnosti a jejich dělení}

Počáteční problém představuje pro badatele na poli diplomatiky v období novověku prvotní orientace v obrovském množství písemného materiálu, který je uchován v archivech. Tradičně se $\mathrm{v}$ našem prostředí písemné dokumenty rozdělují podle tzv. kategorií diplomatického materiálu, které jsou díky fixaci v učebních skriptech dominantním systémem stratifikace. ${ }^{3}$ Již bylo poukázáno na problematičnost tohoto členění, kdy jsou v rámci jednoho schématu použita dvě dělící kritéria - právně-obsahové na listiny, mandáty a listy, zatímco knihy a aktový materiál jsou vymezeny podle formy dochování dokumentů. Přitom knihy i aktový materiál v sobě obsahují zápisy nebo celé písemnosti typu listin, mandátů a listů. ${ }^{4}$ Také v počtu kategorií nepanuje shoda, někdy se mezi ně

1 Sickel, Theodor: Römische Berichte I. Wien, 1895. K tomu také Vašků, Vladimír: Ke dvěma metodologickým otázkám pomocných věd historických. Z pomocných věd historických 13, 1996, s. 81-85.

2 Např. Stloukal, Karel: Česká kancelář dvorská 1599-1608. Pokus z moderní diplomatiky. Praha 1931; Vašků, Vladimír: Studie o správních dějinách a písemnostech moravského královského tribunálu z let 1636-1749. Brno 1969; Šmilauerová, Eva: Správni vývoj a diplomatika písemnosti okresních národních výborů v letech $1945-1960$. Sborník archivních prací (= SAP) 32, 1982, s. 43-169; Sviták, Zbyněk: Z počátki̊ moderni byrokracie. Nejuyšši zeměpanský úrad na Moravě v letech 1748-1782. Brno 2011; Florian, Jaromír: Okresni správa politická v Boskovicích (1919-1928): úřdni jednání, spisová služba a komunikačni písemnosti. Magisterská diplomová práce. Brno 2016.

3 Šebánek, Jindřich - Fiala, Zdeněk - Hledíková, Zdeňka: Česká diplomatika do roku 1848. Praha 1984, s. 20-24.

4 Sviták, Zbyněk: Diplomatika jedna, ne dvě! (Několik úvah). In: Pomocné vědy historické v současné historiografii a archivnictví. Edd. Bláhová, Marie - Holá, Mlada - Woitschová, Klára. Praha 2018, s. 106-107; týž: Potrebujeme tzv. kategorie diplomatického materiálu? Slovenská archivistika 50, 2020, s. 113-122. 
přidává účetní materiál (D. Lehotská), jindy je popírána kategorie knih (H. O. Meisner). ${ }^{5}$ $\mathrm{V}$ německém prostředí se zase prosadilo dělení na dvě nebo tři skupiny (Urkunden Schreiben nebo Urkunden - Akten - Schreiben), ${ }^{6}$ přičemž mandáty jsou chápány jako zvláštní druh listin. ${ }^{7}$

Situace je však složitější a jen stěží lze stále se v čase zvětšující množství písemností vtěsnat do několika kategorií či obecných skupin. Dochované dokumenty jsou odrazem písemné komunikace, která ve společnosti probíhala a stále probíhá ve třech základních rovinách: 8

\section{a) písemný styk správnich i právních instituci s veřejnosti (soukromoprávni oblastí)}

Tuto rovinu lze považovat časově za nejstarší způsob písemné komunikace. Ve starších dobách se omezuje na vztah král - jedinec (šlechtic) nebo instituce (město, klášter), později se rozšiřuje na kontakty správních (nebo později samosprávních) institucí státu s veřejností (jednotlivci nebo právními subjekty). Zeměpán a jím zřízené instituce (státní aparát) svým obyvatelům předává milosti, příkazy, rozhodnutí či oznámení, oni od něj požadují různá povolení (= milosti) v oblastech, které stát reguluje, což žadatelé iniciují ústní nebo později písemnou žádostí.

\section{b) písemná komunikace mezi správními institucemi}

Tato rovina je odrazem pozvolna se rozvíjející správní sítě, která postupně nabývá instanční charakter. V našem prostředí můžeme tento vývoj sledovat od 16. století, akceleruje zejména v pobělohorské době. Vzniká tak sít nadřízených a podřízených správních institucí, jejichž prostřednictvím jsou prosazována zeměpanská (panovnická) nařízení. Od nadřízených úřadů na podřízené přenášejí příkazy, opačným směrem zdola nahoru potom nejrůznější hlášení, dobrozdání a žádosti. Pronikáním státního vlivu na správní instituce stavovského nebo soukromého charakteru dochází k prodlužování správní sítě.

c) písemná komunikace v rámci soukromoprávni oblasti (soukromých osob nebo právnických instituci mezi sebou)

Tato rovina komunikace je také doložitelná již ze středověku, kdykoli, když do písemného vztahu vstupují rovnocenné právnické nebo fyzické subjekty, aby spolu uzavřely

5 Meisner, Heinrich Otto: Urkunden- und Aktenlehre der Neuzeit. Leipzig 1952, s. 15-22; Delort, Robert: Introduction aux sciences auxiliaires de l'histoire, Paris 1969, s. 74-84; Lehotská, Darina: Príručka diplomatiky. Bratislava 1972, s. 6; Szymański, Józef: Nauki pomocnicze historii, Warszawa 2006 ${ }^{6}$, s. 443-447; Jurek, Tomasz (ed.): Dyplomatyka staropolska. Warszawa 2015, s. 18-48; Hochedlinger, Michael: Aktenkunde. Urkunden- und Aktenlehre der Neuzeit, Wien-München 2009, s. 24-46.

6 Dülfer, Kurt: Urkunden, Akten und Schreiben in Mittelalter und Neuzeit. Studien zum Formproblem. Archivalische Zeitschrift 53, 1957, s. 11-53; Vogtherr, Thomas: Urkunden und Akten. In: Aufriss der historischen Wissenschaften, 4: Quellen. Hg. von Michael Maurer, Stuttgart 2002, s. 146-167; Beck, Friedrich -Henning, Eckart (Hg.): Die archivalischen Quellen (Mit einer Einführung in die Historischen Hilfswissenschaften). Köln - Weimar - Wien 20044, s. 9-127.

7 Hochedlinger, M.: Aktenkunde, s. 29-30.

8 Viz Sviták, Zbyněk: Písemná komunikace správních instituci zemépanského charakteru v 17. a 18. století (na př́kladu Moravy). In: Jakž lidé hodnověrní zprávu činí. Formy písemné komunikace v raném novověku. Edd. Hradilová, Marta - Tošnerová, Marie. Praha 2018, s. 60-61. 
smlouvu. Probíhá mimo správní instituce státu a nezávisle na nich, je však významnou měrou ovlivněna správními a právními mechanismy státního aparátu. To se projevuje například napodobováním úředních písemností.

Tyto roviny písemné komunikace produkují množství písemností, jejichž absolutní počet se od konce 15. stol. stále postupem doby zvyšuje. Podobně se rozšiřuje také jejich rozmanitost, když v důsledku společenského a hospodářského vývoje společnosti zasahuje písemná komunikace nové oblasti. Komunikace ve výše zmíněných rovinách představuje poměrně složitou strukturu, která vychází z právního a správního uspořádání konkrétního státu, a určuje prostředí, v jehož rámci jednají a existují jeho obyvatelé. Během historického vývoje prochází změnami a stálým vývojem. Obecně lze říct, že stát stále více zasahuje svými nařízeními do činností obyvatelstva a ovlivňuje tak jeho každodenní život. Něco svými normami výslovně zakazuje a překročení trestá, některé činnosti reguluje a jejich provozování umožňuje pouze na povolení. Pro získání každého takové rozhodnutí vstupuje obyvatel se státem do kontaktu a musí se obrátit na př́slušnou instituci. Správní systém, v němž se realizovaly v 17.-19. století příkazy panovníka, se postupně vyvíjel a získával na rozdíl od dřívějších dob instanční podobu. ${ }^{9}$

V době novověku lze dobře rozlišit několik rovin správních institucí. Nejvyšší představuje panovník, který má k dispozici kabinetní kancelář, kde formuluje zásadní pokyny pro správu monarchie. Pod ní existuje dvorská úroveň správních institucí, které panovníkovy př́íkazy dopracovávají a předávají na úroveň zemskou. Zemská gubernia, případně další vrchní královské úřady se speciálními kompetencemi, organizují správu v rámci zemí a zajištují vykonávání panovníkových nařízení a příkazů. Konkrétní výkon přenášejí na nižší správní úroveň v zemích, reprezentovanou krajskými úřady (v pozdější době nahrazenou rozdělením území na okresy). Ta byla dlouho poslední instancí státní správy, ale od doby Marie Terezie proniká státní dohled formou různých kontrol úradování i dosazováním specializovaných úředníků na poslední, lokální úroveň správy (městské magistráty, vrchnostenské úřady). ${ }^{10}$

Každý vydavatel v rámci kterékoliv z těchto úrovní mohl komunikovat s nadřízenými institucemi (s jedinou výjimkou panovníka), podřízenými instancemi i vydavateli na stejné úrovni správního aparátu (např. královské úřady v jednotlivých zemích, krajské úřady mezi sebou atd.). Nemůžeme si ale komunikaci představovat zcela mechanicky, že by

9 K dějinám státní správy Předlitavska sledovaného období přehledně např. Walter, Friedrich: Österreichische Verfassungs- und Verwaltungsgeschichte von 1500-1955. Wien - Köln - Graz 1972; Hellbling, Ernst, C.: Österreichische Verfassungs- und Verwaltungsgeschichte. Wien - New York 1974; Janák, Jan - Hledíková, Zdeňka - Dobeš, Jan: Dějiny správy v českých zemích od počátků státu po současnost. Praha 2005; k správním dějinám Moravy d'Elvert, Christian: Zur oesterreichischen Verwaltungs-Geschichte mit besonderer Rücksicht auf die böhmischen Länder. Brünn 1880 (= 24. Band der Schriften der historisch-statistischen Section der k. k. Gesellschaft zur Beförderung des Ackerbaues, der Natur- und Landeskunde); Hochedlinger, Michael - Mata, Petr - Winkelbauer, Thomas (Hrsg.): Verwaltungsgeschichte der Habsburgermonarchie in der Frühen Neuzeit I. Wien 2019.

10 Viz Kounicovo schéma správních úřadů; státní zásahy se projevují v regulaci magistrátů nebo existenci justiciáře na patrimoniálních úřadech. Srovnej Janák, J. - Hledíková, Z. - Dobeš, J.: Dějiny správy, s. 144, 235-236. 
se děla pouze podle instančního principu. Záleželo vždy na typu záležitosti, která byla vyřizována.

Jako příklad může posloužit komunikace města, to nekomunikovalo pouze s nadřízenými krajskými úřady, jak by se podle jednoduchého chápání hierarchie správních úrovní mohlo zdát, ale písemný styk probíhal s těmi správními institucemi, které byly pro řešenou záležitost př́íslušné. Například v ekonomických záležitostech město podléhalo podkomořímu a později úřadům městského hospodářství, s rozvojem manufaktur se objevuje nově manufakturní úřad a později komerční konses. V justičních záležitostech je partnerem magistrátu apelační soud v Čechách nebo tribunál na Moravě (od roku 1753 vrchní a apelační soud). Ani samy politické záležitosti nebyly spravovány jedinou institucí, část jich obstarával příslušný nadřízený krajský úřad, na jehož území město leželo, některé z nich, napřríklad povolování divadelních představení, kaváren nebo potvrzování městských rad náleželo nejvyššímu královskému (zeměpanskému) úřadu v zemi.

Ke vzájemné komunikaci mezi institucemi (vydavateli) byly používány vždy zcela specifické písemnosti, příslušející konkrétnímu vydavateli, které mohly být vydávány jen jím a nikým jiným. Použití jejich druhů nebylo tedy libovolné, pro každý typ komunikace existovala zvláštní písemnost, jejíž vzhled se vyvinul u konkrétního vydavatele. ${ }^{11} \mathrm{Z}$ toho vyplývá zásadní provázanost diplomatiky a správy, přitom je ale nutné respektovat jisté odlišnosti mezi správním aparátem jednotlivých zemí habsburské monarchie, v našem případě především v Čechách, na Moravě a ve Slezsku.

Z hlediska orientace po materiálu se proto ukazuje jako účelné rozdělovat diplomatický materiál podle jeho původců. U jednotlivých písemností je tedy nutné vždy identifikovat vydavatele i př́jemce, aby bylo jasné, odkud a kam komunikace směřuje.

\section{Terminologické problémy (pojmenování písemností)}

Písemnosti, které se v rámci písemné komunikace v době novověku používají, nejsou ve velké většině pojmenované. Diplomatika ale doposud identifikovala jen málo z nich, a to pouze z panovnické nebo dvorské úrovně. ${ }^{12}$ Problém je také v tom, že se pro některé druhy písemné produkce, které již diplomatika pojmenovala, vžilo užívání více názvů. Protože se jedná o tutéž písemnost, jsou používaná pojmenování rovnocenná. Jen dobře diplomaticky poučení badatelé tomu odolají, ale většina veřejnosti (mnohé historiky nevyjímaje) mezi nimi je ochotna rozlišovat. Například pro písemnosti na pergamenu a s přivěšenou pečetí je možné používat alternativní názvy listina, privilegium, diplom,

11 Př́iklady písemností používaných v rámci dvorských a zeměpanských institucí viz Sviták, Z.: Písemná komunikace správnich institucí, s. 62-76; týž: Komunikačni pisemnost a její proměny v 17. a 18. století na př́kladu komunikace vídeňského dvora a země (Moravy). In: Formy a premeny diplomatickej produkcie v novoveku I. Edd. Šedivý, Juraj - Valo, Ján. Bratislava 2018, s. 64-80.

12 Viz Stloukal, K.: Česká kanceláŕ dvorská, s. 69-80; Vašků, V.: Studie o správních dějinách, s. 62-91; Šmilauerová, E.: Správni vývoj a diplomatika písemností, s.124-163; Sviták, Z.: Z počátků moderni byrokracie, s. 419-544; Florian, J.: Okresni správa politická, s. 57-62; Hochedlinger, M.: Aktenkunde, s. 171-234; pro pruské prostředí Meisner, H. O.: Urkunden- und Aktenlehre der Neuzeit, s. 27-51; Schmid, Gerhard: Aktenkunde des Staates I. Postdam 1959, s. 114-176. 
konfirmace, vidimus, list na pergamenu nebo majestát. Přitom listiny jako právní pojem mohou nabývat různého vzhledu a vůbec nemusejí být napsány na pergamenu, ale často na papíru, jak je v novověku daleko běžnější. Názvy jako potvrzení, atestace, kvitance, kontrakt, ověření jsou jen další alternativní názvy postihující princip právního chápání stejného pojmu. Nechtěně ale přispívají ke stratifikaci, a tak k hledání zbytečných rozdílů mezi písemnostmi tohoto druhu (listinami), čímž vnášejí terminologické neporozumění do vědecké debaty i obecného diskursu.

Totéž platí i u písemností panovnické kanceláře, které byly uzavřeny pečetí. Středověk je nazývá zavřený list, případně jen list, novověk pak používá termíny jako list posélací, misiva (misiv), později reskript. U těchto písemností se postupně ustálil vzhled s typickou odsazenou intitulací nad textem. Často byly používány k předávání různých pokynů až příkazů a obsahují tedy z hlediska právního obsahu tzv. mandáty. Ale ne všechny, protože mnohé z nich sloužily k pouhému sdělování informací, z právního hlediska obsahovaly listy (jako kategorii písemností). Přitom tzv. mandáty z hlediska právního obsahu mohl vydavatel (panovnická kancelář) expedovat také jinými druhy písemností, jako například dekrety nebo patenty.

Dalším zdrojem terminologického zmatku je přejímání dobového označování písemností, a především nekritické užívání termínů, které byly používány tehdejšími úředníky. Ani oni je totiž nepoužívali systematicky a mnohdy před názvem upřednostňovali označení obsahu. Např́íklad - standardní komunikační písemností mezi dvorskými instancemi a nejvyššími zeměpanskými úřady v 17. a části 18. století byl reskript, jímž byly běžně předávány různé pokyny a nařízení, ale i prostá sdělení. Do různých evidenčních pomůcek, i na rub písemností samotných, je soudobí úředníci zapisovali pod nestejným označením, přestože se jednalo o písemnost ustáleného a stále stejného vzhledu, jednoduše o stejnou písemnost. Bývá označována jako Hof-Rescript, jak odpovídá jejímu názvu, ale nejčastěji Hof-Dekret podle svého obsahu, protože jeho formou byl předáván příkaz. Reskript může ale být označován také jako intimát, insinuát nebo remissorale, jestliže je jeho obsahem pouhé sdělení nebo zpětná odpověd'. ${ }^{13}$ Tyto termíny neoznačují nějaké zvláštní typy písemností, ale pouze specifikují funkci v komunikaci a upozorňují na obsah. Z uvedených příkladů plyne, že v současné praxi pojmenovávání druhů písemných dokumentů se mísí dobově užívané termíny i názvy pro již dříve zavedené kategorie diplomatického materiálu s právním obsahem písemností.

Cestou z terminologického zmatení je rozlišování dvou rovin každé písemnosti. První rovinu představuje její layout, tedy konkrétní fyzický vzhled společně s jejím vnitřním uspořádáním (pořadím formulí dokumentu). Druhá rovina je právně-obsahová a je určena obsahem písemnosti a jeho právním charakterem.

Layout písemností vychází ze dvou aspektů analýzy diplomatického materiálu, totiž z tzv. vnitřních a vnějších znaků písemností. ${ }^{14}$ Lze konstatovat, že vzhled a vnitřní uspořá-

13 Viz význam termínů např. v Roubík, František - Haas, Antonín - Kollman Josef - Fiala, Zdeněk (zprac.): Slovnićek archiuni terminologie. Praha 1954, s. 20.

14 Pojem je běžně používaným viz např. Bresslau, Harry: Handbuch der Urkundenlehre für Deutschland und Italien I, Leipzig 1912, s. 5-6; Meisner, H. O.: Urkunden- und Aktenlehre der Neuzeit, s. 97-141; Šebánek, J. - Fiala, Z. - Hledíková, Z.: Česká diplomatika, s. 29-34; Hochedlinger, M.: Aktenkunde, s. 118-170. 
dání dokumentů je bezprostředně svázán s konkrétním vydavatelem, u něhož písemnost vznikla. Odpovídá intelektuálním a technickým možnostem jeho diplomatického prostředí. Lze konstatovat, že každý vydavatel používá k vyřizování záležitostí své specifické druhy písemností, které se u jednotlivých vydavatelů od sebe vzájemně více či méně odlišují. Z jeho kanceláře vychází pouze konečný počet druhů, jejichž prostřednictvím vyřizuje všechny záležitosti. Obecně také neplatí, že by bylo možné druh písemného dokumentu vždy spojit s určitým obsahem. ${ }^{15}$ Jejich layout se v čase postupně vytváří a zdokonaluje, což se projevuje upevňováním formuláře a fixací částí textu na pevných místech. ${ }^{16}$ Layout písemností jednotlivých kanceláří se může ovlivňovat. Zejména vydavatelé na nižším stupni společenského žebříku obvykle napodobují formu písemné produkce výše postavených, a to zejména proto, aby zvýšili u svých písemností solidnost a věrohodnost a také jim dodali odlesk vyššího postavení. Nápodoba jde vždy jen do jisté míry, nikdy se nejedná o úplné převzetí vzoru. Stále přitom platí, že písemnosti kanceláře českého krále budou v principu jiné než písemnosti kanceláří jiných králů, polského, francouzského či jiného krále, stejně tak bude rozdílná písemná produkce papežské kanceláře od písemností jiných církevních hodnostářů.

Druhou rovinu písemnosti určuje její obsah ovlivněný jeho právním charakterem. Podle právně-obsahového kritéria lze dokumenty rozdělit do více skupin. Ty nemají nahradit dosavadní kategorie, ale postihnout diplomatický materiál podle charakteru jeho obsahu a poukázat na daleko barvitější obsahovou stránku historických pramenů (např. listiny, mandáty, normativní nařízení, hlášení, žádosti, pamětní záznamy, prostá sdělení, oficiální zápisy, předlohy, evidenční záznamy, účty atd.). Nelze také vyloučit, že budou mezi dokumenty takové písemnosti, které podle právního obsahu budou moci být zařazeny do dvou (nebo i více) skupin. Takové přechodné typy vyplývají z charakteru historických pramenů a života vůbec.

Ve zmíněných dvou rovinách lze posoudit každou písemnost, at má podobu jednotliviny nebo souboru, knihy či spisu, její konečná charakteristika bude určena prolnutím těchto dvou hledisek. Přihlédnutí $\mathrm{k}$ nim může představovat východisko ze současných terminologických nejasností. ${ }^{17}$

\section{Oddělení terminologie diplomatiky od archivnictví (ukládání archiválií)}

Při chápání novověkých písemností se projevuje zásadní závislost diplomatiky na archivní praxi. Nepochybně se tu projevuje vliv archivních příruček, které popisují v archivech uložený písemný materiál a v podstatě předkládají návod, jak jej strukturovat

15 Například pro mandát (nařízení) bylo možné použít patent (otevřený list), dekret nebo zavřený list (misivu, list posélací). Svědectví o právní skutečnosti (listinu) bylo možné udělit písemností různých layoutů, s přivěšenou, přitištěnou i uzavírací pečetí.

16 Např. fixace části textu nebo kancelářské poznámky na vyhrazeném místě psací látky, pozdější doplňování dalších atributů písemnosti (např. podpisů pod textem, kde se dosud neobjevovaly).

17 K navrženému schématu podrobněji Sviták, Z.: Potřebujeme tzv. kategorie diplomatického materiálu, s. 116-119. 
a spravovat. ${ }^{18}$ Vycházejí přitom z obecných zvyklostí ukládání materiálu v registraturách př́jemců, kde byl pravidelně historicky rozdělován na sbírky listin, knihy a aktový materiál. Toto schéma představuje v archivním prostředí základní princip. Stalo se také vzorem pro tzv. kategorie diplomatického materiálu, formulované skripty pro výuku diplomatiky a díky výuce hluboce zakořeněné v paměti všech archivářů.

Nelze se proto divit, že všechny práce o novověké diplomatice začínají rozborem druhů archivního materiálu. Jejich autoři se při jeho dělení odrážejí od popisu archivních pramenů a v registraturách uloženého (a tím v podstatě rozděleného) písemného materiálu, od něhož se pak odvíjí použitá terminologie i klasifikace písemností. ${ }^{19}$

Jestliže je toto schéma rozdělování písemného materiálu vhodné pro praktické ukládání v archivech, nemusí vyhovovat diplomatice. Ta se totiž sice zabývá obecně písemnostmi vcelku, ale každou z nich posuzuje jako jednotlivinu. Z praktických potřeb vycházející ukládání písemností na listiny, knihy a aktový materiál se dostává do rozporu s diplomatickým chápáním písemností.

Například, v každé archivní sbírce listin, která obvykle tvoří první část fondu, skutečně mimo pergamenových privilegií nalezneme i písemnosti na papíře, které podle právního obsahu můžeme označit jmény kategorií jako mandáty nebo listy. ${ }^{20}$ Tato část je pravidelně označena jako „listiny“, přestože zde nalezneme listiny, mandáty a listy.

Nová archivní pravidla, která pro evidenční účely potřebují sečíst položky v těchto sbírkách, operují s termínem „Listiny do roku 1850“, které definují jako „Privilegia, majestáty, diplomy, ochranné a lenní listy ... patenty, reskripty, (dvorské) dekrety, cechovní artikule, notářské instrumenty. Pokud jsou součástí těchto sbírek i listy, jsou evidovány rovněž jako listiny“. ${ }^{21}$ Tím ovšem prohlubují obecné terminologické zmatení, protože ne každý si uvědomí, že takovýto výklad pojmu „listina“ je pouze archivně-evidenční a rozhodně neodpovídá diplomatickému vymezení pojmu.

Souvisejícím problémem je nereflektování výuky novověké diplomatiky v archivní praxi. Je vždy při tvorbě inventářů nebo katalogů dbáno na terminologii, především na názvy písemností, s nimiž se posluchači na přednáškách seznamují? Zdá se, že se tato výuka zcela míjí účinkem a nezanechává v praktické činnosti stopy. Konkrétní názvy typů písemností inventární nebo katalogizační popisy většinou neobsahují, přestože tato informace nemusí být zbytečná. Takový mandát (příkaz) může být vyjádřen např. patentem (otevřeným listem), listem posélacím (zavřeným listem) nebo dekretem.

18 Např. Hrubý, Václav: Úvod do archivní teorie a prakse. Praha 1930, s. 9-11; Čechová, Gabriela a kol.: Archivni pŕiručka. Praha 1965, s. 38-42. Srovnej rovněž dělení inventarizace a katalogizace v metodických pokynech pro archiváře (Metodické návody a instrukce pro zpracováni archivního materiálu, SAP 10, 1960, s. 227-236). Viz také strukturu archiválií u krajských úřadů (Macek, Jaroslav - Žáček, Václav: Krajská správa v českých zemich a jeji archiuní fondy. Praha 1958, dochované archiválie jednotlivých institucí).

19 Meisner, H. O.: Urkunden- und Aktenlehre der Neuzeit, s. 15-26; Hochedlinger, M.: Aktenkunde, s. 23-46.

20 Nalézají se tu i písemnosti jiné, které byly do této části registratury vloženy. V inventářích jsou označeny jako „listiny“. Oddělení „Listiny“ lze nalézt prakticky ve všech fondech s materiálem ze starší doby, typické jsou pro archivy měst. Pouze Archiv města Brna nazývá tuto sbírku ve fondu „Archiv města Brna“ odpovídajícím způsobem - Sbírka listin, mandátů a listů. Viz Dřímal, Jaroslav: Archiv města Brna. Průvodce po fondech a sbírkách. Praha 1956, s. 39-45.

Wanner, Michal a kol.: Základni pravidla pro zpracováni archiválii. Praha 2015, s. 25-26. 


\section{Nestejnoměrný rozvoj bádání}

Před diplomatikou v době novověku stojí velké úkoly, protože mnohé části písemného vývoje nebyly dosud zpracovány. Nejlepší situace panuje u panovnické kanceláře (české královské v Praze i české dvorské ve Vídni), jejíž činnosti a písemnostem byla tradičně věnována největší pozornost. Ne tak dobrá je situace u dalších institucí vídeňského dvorského prostředí, jejichž písemnosti se nestaly předmětem samostatných studií. Práce o jejich kancelářích se věnují většinou správnímu vývoji, personálnímu obsazení kanceláře, případně kancelářskému chodu. To platí i o vrcholných správních institucích zeměpanského charakteru v Čechách, u české komory, apelačního soudu nebo nejvyššího zeměpanského úřadu (místodržitelství, reprezentace a komory, gubernia). ${ }^{22} \mathrm{Na}$ Moravě je v tomto ohledu situace příznivější, protože tribunál a gubernium se dočkalo diplomatického zpracování, ${ }^{23}$ zatímco moravsko-slezské gubernium zatím setrvává na správní rovině. ${ }^{24}$ Nejvyšší zeměpanský úřad ve Slezsku zatím na své diplomatické zpracování čeká.

Vydavatelé (instituce) na nižších úrovních správního aparátu jsou zpracovány minimálně a to jen ze správního hlediska (krajské úřady). ${ }^{25}$ Zdaleka nejpř́íznivější situace panuje u zpracování novověkých diplomatických poměrů městských kanceláří, nebot̉ městské prostředí tradičně patří do oblasti zvýšeného historického zájmu. V bádání ale převažuje zájem o 16. století, městské kanceláře v 17. a 18. století jsou prozkoumány jen okrajově. ${ }^{26}$ Sondážně je zpracováno vrchnostenské prostředí nebo písemnosti církevních institucí, i když i tady se sleduje spíše správní vývoj. Až na výjimky nebyly předmětem zájmu diplomatiky účetní písemnosti nebo obecně diplomatická produkce 19. a 20. století. ${ }^{27}$

Nestejnoměrný rozvoj bádání $\mathrm{v}$ naznačených oblastech je příčinou, že nemáme dostatečně zpracovány typy písemností různých vydavatelů, takže máme jen omezenou představu o jejich funkci ve vzájemné písemné komunikaci. Díky tomu důsledně

22 Např.: Gross, Lothar: Die Geschichte der deutschen Reichshofkanzlei von 1559 bis 1806. Wien 1933; Reinhöhl, Fritz: Geschichte der k. u k. Kabinettskanzlei. Mitteilungen des Österreichischen Staatsarchivs 7 (suplement), 1963; Pešák, Václav: Dějiny královské české komory od roku 1527. Sborník archivu ministerstva vnitra (= SAMV) 3, 1930; týž: Studie k dějinám králouské české komory, SAMV 6, 1933, s. 66-178; Roubík, František: Mistodržitelství v Čechách v letech 1577-1749. SAP 17, 1967, s. 539-603; týž: K vývoji zemské správy v Čechách v letech 1749-1790. SAP 19, 1969, s. 41-188; Adamová, Karolína: Apelačni soud v českém královstvi v letech 1548-1651. In: Pocta akademiku Václavu Vaněčkovi k 70. narozeninám, Praha 1975, s. 101-112; Hausenblasová, Jaroslava: Počátky apelačního soudu v Čechách a jeho personální obsazeni 1548-1627. Paginae historiae 13, 2005, s. 5-31; Šalak, Boris: Organizace a působnost apelačního soudu v Praze v době tereziánské. SAP 63, 2013, s. 66-130.

23 Viz Vašků, V.: Studie o správních dějinách, s. 49-105; Sviták, Z.: Z počátků moderni byrokracie, s. 419-544.

24 Brodesser, Slavomír: Moravskoslezské gubernium v letech 1783-1849. Netištěná rigorosní práce. Brno 1968.

25 Rieger, Bohuš: Zřizeni krajské v Čechách. Praha 1892-1894; Sedláčková, Helena: Krajšti hejtmané v Čechách (1537-1848). Netištěná disertační práce. Praha 2016.

26 Viz přehledně Vojtíšková, Jana: $Z$ dosavadního výzkumu městských kanceláři v Čechách v době 18. století (zejména na př́ikladu vybraných východočeských královských věnných měst). Cornova 10, 2020, s. 71-83.

27 Kromě citovaných prací Evy Šmilauerové a Jaromíra Floriana viz např.: Šopfová, Marta: Písemnosti okr. hejtmanstvi na Moravě. Folia diplomatica 8, 1959-1960, s. 1-20; Koštál, Miloslav: Písemnosti lesních úřadi̊ v okupovaném pohraniči 1938-1954 (Jejich typy a hodnocení). Archivní časopis 16, 1966, s. 91-101; Fejlková, Alena: Správni vývoj a diplomatika písemností resortu energetiky v Československu v letech 1945-1969. SAP 38, 1988 , s. $483-525$. 
nerozlišujeme, zda byly používány pro komunikaci s nadřízenými, podřízenými či vydavateli na stejné úrovni správního aparátu nebo se jedná o písemnosti pro veřejnost a strany. ${ }^{28}$ Nevíme také, jak široká byla paleta užívaných typů písemných dokumentů. Teprve na základě specializovaných studií a sond bude možné posunout bádání o diplomatice novověku na vyšší úroveň.

\section{General Problems of Diplomatics of Early and Late Modern Period}

The article deals with the causes of insufficient reflection of written production in the early and late modern period. It identifies the amount of documents and the issue of their division as the main obstacles to research insofar as they are a prerequisite for mastering the written material. Other problems relate to terminology issues (giving the same document different names), diplomatic terminology's over reliance on archival practice and the uneven depth of development in the various areas of early and late modern diplomatics.

From the perspective of the approach to the material, it is expedient to divide diplomatic material according to its origin. For individual written documents, it is therefore necessary to identify both the issuer and the recipient, so that it is clear where the communication came from and where it went.

As a way out from the terminology obstacles in the naming of different types of written documents, the study proposes distinguishing between two levels with regard to each particular archival material. The first level is the layout of the document, i.e., its specific physical appearance along with its internal arrangement (the order of the document's parts). The second level is legal-content aspect, which is determined by the content of the document and its legal character.

The terminology of early and late modern diplomatics essentially adopts archival nomenclature, which overly respects the division of written material according to the way it is stored in registres. From an archival point of view, these groupings are logical, but from the diplomatic perspective, they contain documents of various types and are not homogeneous. The terminology of archival science and diplomatics must be kept apart. A consequence of this situation is also the fact that the teaching of diplomatics is not reflected in archival inventories. Is it then even necessary to teach it?

The heterogeneous development of research in various areas is the reason why we do not have sufficient processed types of documents from diverse issuers, and therefore we only have a limited idea of their function in mutual written communication. As a result, we do not consistently distinguish whether they were used for communication with superiors, subordinates or issuers at the same level in the administrative apparatus, or whether they were documents intended for the public or other parties. Neither do we know the extent of the range of types of written documents. It will only be possible to take research into early and late modern diplomatics to a higher level on the basis of specialized studies.

28 K rozdělení písemností viz Sviták, Zbyněk: Jak rozdělovat písemnosti u konkrétniho vydavatele? $\mathrm{V}$ tisku. 